\title{
ANALISA PEMBIAYAAN PROPERTI MENGGUNAKAN AKAD MMQ (MUSYARAKAH MUTANAQISAH)
}

(Studi Kasus Pada Bank Muamalat Indonesia)

\author{
Edwin Rahmat Yulianto, ME \\ Dosen Fakultas Agama Islam As Syafiiyah Jakarta \\ edwynrahmat@gmail.com
}

\begin{abstract}
ABSTRAK - Penelitian ini bertujuan untuk mengetahui bagaimana aplikasi akad Musyarakah Mutanaqisah (MMQ) pada Bank Muamalat Indonesia. Penelitian ini bersifat kualitatif berbasis deskriptif dengan melakukan studi lapangan (field reaserch). Penelitian ini menggunakan analisis SWOT, yaitu dengan menganalisa faktor internal yaitu kekuatan, kelemahan, serta menganalisa faktor eksternal yaitu peluang maupun ancaman dari akad tersebut. Hasil dari penelitian ini adalah terdapat beberapa kelemahan pada akad Musyarakah Mutanaqisah (MMQ), yang menyebabkan akad ini belum maksimal pada peningkatan profit Bank Muamalat Indonesia.
\end{abstract}

ABSTRACT - This study aims to determine how the application of the Musyarakah Mutanaqisah (MMQ) contract at Bank Muamalat Indonesia. This research is a descriptive qualitative based by conducting field reaserch. This study uses a SWOT analysis, by analyzing internal factors, strengths and weaknesses, and analyzing external factors, opportunities and threats of the contract. The results of this study are that there are some weaknesses in the Musyarakah Mutanaqisah (MMQ) contract, which causes this contract to not be maximized in increasing the profit of Bank Muamalat Indonesia.

\section{PENDAHULUAN}

Properti adalah salah satu ketersedian perumahaan. Hal itu kebutuhan primer masyarakat, terutama menyebabkan semakin tingginya harga di daerah perkotaan. Tingginya jual dari sektor properti terutama pertumbuhan penduduk dan kebutuhan properti residensial. Keterbatasan lahan tempat tinggal tidak simultan dengan adalah salah satu faktor yang membuat 
House Price Index (HPI) menjadi meningkat seiring dengan meningkatnya pertumbuhan penduduk. Dengan meningkatnya prospek bisnis properti tentu saja peran perbankan menjadi sangat penting dalam segi pembiayaan. Menurut data Bank Indonesia, pembelian rumah konsumen di Indonesia sebagian besar masih menggunakan Kredit Pembiayaan Rumah (KPR). Dengan adanya KPR maka solusi untuk memiliki rumah bisa dengan mudah terwujud. Hal tersebut di buktikan pada Triwulan IV-2018, presentase konsumen melakukan pembelian rumah dengan menggunakan KPR sebanyak 76,73\%, lebih rendah dari triwulan sebelumnya sebesar 77,20\%. Sedangkan konsumen yang membeli rumah dengan tunai bertahap meningkat dari $15,12 \%$ menjadi $15,86 \%$.

Begitu pula dengan kredit berbasis syariah, menurut Housing Finance Information terlihat dari nilai total kredit syariah bulan Februari 2019 sebesar Rp320,98 triliun, mampu tumbuh 13,79\% (yoy) dibandingkan total kredit syariah pada bulan Februari
2018 sebesar Rp282,10 triliun. Pertumbuhan total kredit syariah tersebut sejalan dengan meningkatnya nilai outstanding KPR syariah. Pada bulan Februari 2019, nilai outstanding KPR syariah mencapai $\mathrm{Rp} 72,30$ triliun atau meningkat 18,28\% (yoy) dibandingkan outstanding KPR syariah bulan Februari 2018 sebesar Rp61,13 trilun. Pertumbuhan KPR syariah tersebut lebih tinggi dibandingkan pertumbuhan KPR nasional sebesar 13,71\% (yoy) pada bulan yang sama.

Seiring dengan meningkatnya pertumbuhan KPR Syariah mengharuskan Bank Syariah menciptakan pembiayaan yang inovatif, maka DSN MUI mengeluarkan akad yaitu Musyarakah Muttanaqisah (MMQ). Akad tersebut yang kemudian juga digunakan pada KPR iB Muamalat Kongsi dari Bank Muamalat Indonesia (BMI). Berdasarkan permasalahan diatas maka peneliti memandang penting untuk melakukan penelitian lebih lanjut tentang bagaimana aplikasi akad Musyarakah Mutanaqisah (MMQ) pada pembiayaan KPR iB Muamalat. 


\section{LANDASAN TEORI}

Akad Musyarakah

a. Konsep Dasar Musyarakah

Secara bahasa (lughatan), kerja sama (al-syirkah) adalah percampuran antara sesuatu dengan yang lain sehingga sulit dibedakan. Adapun menurut istilah, kerja sama (syirkah) adalah keikutsertaan dua orang atau lebih dalam suatu usaha tertentu dengan sejumlah modal yang telah ditetapkan berdasarkan perjanjian untuk bersamasama menjalankan suatu usaha dan pembagian keuntungan atau kerugian dalam bagian yang ditentukan. Atau, akad kerjasama antara dua pihak atau lebih untuk usaha tertentu yang masingmasing pihak memberikan kontribusi dana (al-mal/expertise) dengan kesepakatan bahwa keuntungan dan risiko akan ditanggung bersama sesuai dengan kesepakatan (Firdaus at al., 2005: 43)

Pendapat lain dikemukakan oleh Az-Zuhaily (1989: 792-793) musyarakah adalah akad kerjasama antara dua pihak atau lebih untuk usaha tertentu yang masing-masing pihak memberikan kontribusi dana dengan kesempatan bahwa keuntungan dan risiko akan ditanggung bersama sesaui dengan kesepakatan.

Seperti halnya mudharabah, musyarakah adalah akad kerjasama atau usaha dua atau lebih pemilik modal atau keahlian untuk melakukan jenis usaha yang halal dan produktif. bedanya dengan mudharabah adalah dalam hal pembagian untung rugi dan keterlibatan peserta dalam usaha yang sedang dikerjakan (Nawawi, 2012: 151).

\section{b. Jenis-jenis Musyarakah}

Secara garis besar Az-Zuhaily (1989: 976) menyatakan, musyarakah dibagi menjadi dua jenis yakni musyarakah kepemilikan (syirkah alamlak) dan musyarakah akad (syirkah al-aqd). Syirkah kepemilikan tercipta karena warisan, wasiat atau kondisi lain yang mengakibatkan pemilikan satu aset oleh dua orang atau lebih dalam musyarakah ini kepemilikan dua orang atau lebih terbagi dalam dua aset nyata dan berbagi dari keuntungan yang dihasilkan aset tersebut.

Musyarakah akad tercipta karena kesepakatan dua orang atau lebih yang menyetujui bahwa tiap-tiap orang dari mereka memberikan konstribusi dari modal musyarakah. Mereka pun sepakat 
berbagai keuntungan dan kerugian musyarakat akad terbadi menjadi syirkah al-inan, al-mufadhah, al-amal dan syirkah al-wujuh.

Pembagian syirkah yang disampaikan oleh Az-Zuhaily tersebut senada dengan syirkah yang diungkapkan oleh Firdaus at al., (2005: 45-49) bahwa para ulama membagi syirkah ke dalam bentuk - bentuk dijelaskan dibawah ini :

a. Kontrak antara dua orang atau lebih (syirkah al-inan) adalah kontrak setiap pihak memberikan suatu porsi dari keseluruhan dana dan berpartisipasi dalam kerja kedua pihak berbagi dalam keuntungan dan kerugian. Sebagaimana yang disepakati di antara mereka namun porsi masing-masing pihak baik dalam dana maupun kerja atau bagi hasil berbeda sesuai dengan kesepakatan mereka, semua ulama membolehkan jenis musyarakah ini. Mazhab Hanafi dan Hanbali mengizinkan salah satu dari alternatif berikut, pertama keuntungan dari kedua pihak dibagi menurut porsi dana mereka, kedua keuntungan bisa dibagi secara sama tapi kontribusi dana masing-masing pihak mungkin berbeda ketiga keuntungan bisa dibagi secara tidak sama tapi dana yang diberikan sama ibnu qudamah mengatakan "Pilihan dalam keuntungan diperbolehkan dengan adanya kerja, karena seorang dari mereka mungkin lebih ahli dalam bisnis dari yang lain dan ia mungkin lebih kuat ketimbang yang lainnya, dalam melaksanakan pekerjaan karenanya ia dizinkan untuk menuntut lebih dari bagian keuntungannya". Mazhab Maliki dan Syafi'i menerima jenis musyarakah ini dengan syarat keuntungan dan kerugian dibagi secara proposional sesuai dana yang ditanamkan dalam pandangan merek keuntungan jenis musyarakah ini dianggap keuntungan modal.

b. Syirkah mufawadhah adalah kontrak kerja sama antara dua orang atau lebih setiap pihak memberikan suatu porsi dari keseluruhan dana dan berpartisipasi dalam kerja. Setiap pihak membagi keuntungan dan kerugian secara sama. Dengan demikian syarat utama dari jenis musyarakah ini adalah kesamaan dana yang diberikan, kerja tanggung jawab dan beban utang dibagi oleh 
masing-masing pihak. Mazhab Hanafi dan Maliki membolehkan musyarakah jenis ini tetapi, memberikan banyak batasan terhadapnya yang paling penting dalam perserikatan ini baik modal kerja keuntungan maupun kerugian mempunyai hak dan kewajiban yang sama. Sementara menurut ulama Syafi'iyah dan Hanabilah tidak membolehkan akad seperti ini karena sulit untuk menetapkan prinsip kesamaan modal kerja, dan keuntungan dalam perserikatan ini.

c. Syirkah a'mal adalah kontrak kerjasama dua orang seprofesi untuk menerima pekerjaan secara bersama dan berbagi keuntungan dari pekerjaan. Misalnya kerja sama dua orang arsitek untuk menggarap sebuah proyek atau kerjasama dua orang penjahit untuk menerima order pembuatan seragam sebuah kantor, Musyarakah ini kadang-kadang disebut musyarakah abdan. Mazhab Hanafi, Maliki dan Hanbali membolehkan musyarakah ini baik kedua orang tersebut satu profesi maupun tidak. Mereka merujuk kepada bukti-bukti termasuk persetujuan terbuka dari Nabi, hal ini didasarkan kepada perwakilan (wakalah) yang juga dibolehkan dalam musyarakah jenis ini telah lama dipraktikkan.

d. Syirkah wujuh adalah kontrak antara dua orang atau lebih yang tidak memiliki modal sama sekali tetapi mempunyai keahlian dalam bisnis mereka. Membeli barang secara kredit suatu perusahaan dan menjual barang tersebut secara tunai, mereka berbagi dalam keuntungan dan kerugian berdasarkan jaminan kepada penyuplai yang disediakan oleh tiap mitra. Jenis musyarakah ini tidak memperlukan modal karena pembelian secara kredit berdasarkan jaminan tersebut. Maka kontrak ini pun lazim disebut seabgai musyarakah piutang. Para ulama memperselisihkan perserikatan seperti ini ulama Hanafiyah, Hanabilah, dan Zaidiyah menyatakan, hukumnya boleh karena masing- masing pihak bertindak sebagai wakil dari pihak lain, sehingga pihak lain tersebut terikat pada transaksi yang telah dilakukan oleh mitra serikatnya. Akan tetapi menurut ulama Malikiyah, Safi'iyah, Zahiriyah dan Syi'ah Imamiyah, 
perserikatan ini tidak sah dan tidak dibolehkan, alasannya objek dalam perserikatan ini adalah modal dan kerja sedangkan dalam syirkah alwujuh baik modal maupun kerja yang diakadkan tidak jelas.

e. Kontrak kerja sama antara Pemilik modal dan seorang pekerja untuk mengelola uang dari pemilik modal dalam perdagangan tertentu (Syirkah al-mudharabah) keuntungannya dibagi sesuai kesepakatan bersama,

\section{c. Rukun dan Syarat Musyarakah \\ Az-Zuhaily (1989: 805) dan}

Firdaus at al., (2005: 48-49) menyebutkan rukun dan syarat musyarakah yang intinya dijelaskan dibawah ini.

a. Rukun Musyarakah

1. Ucapan (sighah) penawaran dan penerimaan (Ijab dan qabul)

2. Pihak yang berkontrak

3. Objek kesepakatan berupa modal dan kerja,

\section{b. Syarat Musyarakah}

1. Ucapan: tidak ada bentuk khusus dari kontrak musyarakah, ia dapat berbentuk pengucapan yang menunjukkan tujuan sedangkan kerugian yang diderita menjadi tanggung jawab pemilik modal, Menurut mazhab Hanabilah, mudharabah termasuk salah satu bentuk persertikatan, tetapi menurut jumhur ulama (Hanafiyah, Malikiyah, Syafi'iyah, Zahiriyah, dan Syi'ah Imamiyah) tidak memasukkan termasuk mudharabah sebagai salah satu bentuk perserikatan karena akad ini merupakan akad yang tersendiri.

berakad dianggap sah jika diucapkan secara verbal atau ditulis kontrak musyarakah dicatat dan disaksikan.

2. Pihak yang berkontrak: disyaratkan bahwa mitra harus kompeten dalam memberikan atau diberikan kekuasan perwakilan.

3. Objek Kontrak (dana dan kerja) dana atau modal yang diberikan harus uang tunai emas, perak atau yang bernilai sama, para ulama menyepakati hal ini, beberapa ulama memberi kemungkinan pula bila modal berwujud aset perdagangan, seperti barang- 
barang properti, perlengkapan, dan sebagainya, bahkan dalam bentuk hak yang tidak terlihat seperti lisensi hak paten dan sebagainya, bila itu ditakutkan menurut kalangan ulama seluruh modal tersebut harus dinilai lebih dahulu secara tunai dan disepakati oleh mitranya.

Mahzab Syafi'i dan Maliki mensyaratkan dana yang disediakan oleh masing-masing pihak harus dicampur, tidak dibolehkan pemisahan dana dari masing-masing pihak untuk kepentingan khusus, misalnya yang satu khusus membiayai bahan baku dan yang lainnya hanya membiayai pembelian perlengkapan kantor. Tetapi mazhab Hanafi tidak mencantumkan syarat ini jika modal itu dalam bentuk tunai sedangkan Mazhab Hanbali tidak mensyaratkan pencampuran dana.

Partisipasi para mitra dalam pekerjaan musyarakah adalah ketentuan dasar, tidak dibenarkan bila salah seorang diantara mereka menyatakan tak akan ikut serta menangani pekerjaan dalam kerjasama itu, namun tidak ada keharusan mereka menanggung beban kerja secara bersama, salah satu pihak boleh menangani pekerjaan lebih dari yang lain dan berhak menuntut pembagian keuntungan lebih bagi dirinya.

\section{d. Hukum Musyarakah}

Pelaksanaan Musyarakah

mengandung aspek-aspek hukum secara operasional yang dikemukakan oleh Firdaus at al., (2005: 49-55) secara terperinci dijelaskan dalam uraianuraian dibawah ini:

\section{a. Hukum Tentang Modal}

Berikut ini dicantumkan ketentuan berkaitan dengan pengawasan operasi modal dan pemeliharaannya.

1. Kekuasaan perwakilan dan pengaturan

Seorang mitra memiliki hak untuk mengatur aset musyarakah dalam proses bisnis normal seorang mitra memiliki hak untuk mengatur aset (seperti dalam al-inan) menciptakan sebuah kesatuan dana, lalu setiap mitra memberi wewenang mitra lainnya untuk mengatur aset seorang diniali berhak atas wewenang itu. Bila ia menggunakannya secara baik, dengan memelihara kepentingan mitra lainnya, seorang mitra tidak diizinkan untuk mencairkan 
atau menginvestasikan dana untuk kepentingannya sendiri.

2. Modal yang tidak dijamin Seorang mitra tidak bisa menjamin modal mitra lainnya, karena musyarakah berdasarkan prinsip al-ghunтu bil ghummi yaitu hak untuk mendapat keuntungan berhubungan dengan risiko yang diterima, tetapi seorang mitra dapat meminta mitra yang lain untuk menyediakan jaminan atas kelalaian atau kesalahan yang disengaja.

b. Hukum Tentang Pekerjaan

Dalam musyarakah yang menggunakan penyetoran modal, setiap mitra harus menyediakan pekerjaan, masing-masing mitra melaksanakan kerja sesuai kontrak musyarakah tersebut hal ini diatur oleh hukum-hukum fikih diantaranya sebagai berikut:

1. Perwakilan dalam kerja

Setiap mitra melaksanakan kerja dalam musyarakah datas nama pribadi dan wakil mitranya ini diatur oleh hukum dasar dari kontrak perwakilan dalam fikih Islam beberapa dari hukum ini berhubungan dengan pimpinan sebagian berhubungan dengan wakil dan sebagai lainnya berhubungan dengan hal-hal yang menjadi objek perwakilan semua ini harus dijelaskan dalam kontrak musyarakah.

2. Wilayah

Pengaturan ini menyangkut penentuan wilayah kerja bagi setiap mitra pekerjaan ini, termasuk urusan manjemen bisnis seperti perencanaan, pembuatan kebijakan, pengembangan program eksekutif, tindak lanjut, supervisi, penilaian kinerja dan pembuatan keputusan. Kontrak musyarakah seharusnya memuat pengaturan kerja bagi setiap mitra termasuk masalah lalai atau kesalahan yang disengaja. Seorang mitra yang melaksanakan pekerjaan di luar wilayah tugas yang ia sepakati, berhak mempekerjakan orang lain untuk menangani pekerjaan tersebut. Jka ia sendiri melakukan pekerjaan, ia berhak menerima upah yang sama dengan yang dibayar untuk pekerjaan di tempat lain, tapi beberapa ulama membolehkan seorang mitra mewakilkan penuh kepada yang lain untuk melaksanakan bisnis 
musyarakah tersebut jika pilihan itu dianggap yang terbaik bagi pelaksanaan musyarakah.

3. Penunjukkan Pekerja

Seorang mitra dapat menunjuk pekerja untuk melaksanakan tugas diluar wilayah kerja perorangan. Ongkos pekerjaan tersebut merupakan tanggungan musyarakah jika seorang mitra memperkerjakan orang lain untuk melaksanakan tugas yang menjadi bagiannya. Ongkos yang timbul harus ditanggungnya sendiri, penunjukkan pekerja sepenuhnya bergantung pada keperluan dan mereka harus menerima upah karenanya

4. Pinjaman meminjamkan hadiah dan sumbangan sosial

Mitra tidak boleh meminjamkan uang atas nama Musyarakah demikian juga meminjamkan uang kepada pihak ketiga dari modal musyarakah menyumbangkan atau menghadiahkan uang tersebut, kecuali hal itu telah disepakati dengan mitra lainnya.

c. Hukum Tentang Keuntungan

Keuntungan harus dikuantifikasi atau dinilai jumlahnya, Hal tersebut untuk mempertegas dasar kontrak musyarakah agar tidak mengarah pada perbedaan dan sengketa pada waktu alokasi keuntungan dan penghentian musyarakah. Jika para mitra mengatakan bahwa "Keuntungan akan dibagi diantara kita" maka dalam hal ini keuntungan akan dialokasikan menurut saham masing-masing dalam modal.

Setiap keuntungan harus merupakan bagian proposional dari seluruh keuntungan. Musyarakah seorang mitra tidak dibenarkan untuk menentukan bagian keuntungannya sendiri pada awal kontrak, karena hal itu melemahkan musyarakah dan melanggar prinsip keadilan. Seorang mitra boleh mengusulkan bahwa jika keuntungan melebihi jumlah tertentu, kelebihan atau persentase itu diberikan kepadanya, contohnya bila seorang dari mereka (mitra) mengatakan "saya akan mendapat sepuluh jika kita mendapatkan lebih dari itu", dan mitra lainnya menyepakati, kontrak tersebut sah, syarat-syarat tersebut pun bersifat mengikat (Nawawi, 2012: 157).

$$
\begin{aligned}
& \text { d. Hukum Tentang Alokasi } \\
& \text { Keuntungan Bagi Mitra } \\
& \text { Para ulama berbeda pendapat dalam } \\
& \text { masalah alokasi keuntungan di antara }
\end{aligned}
$$


para mitra berikut ini adalah ringkasan pendapat-pendapat tersebut .

1. Pembagian keuntungan proporsional sesuai modal

Menurut pendapat ini keuntungan harus dibagi diantara para mitra secara proporsional sesuai modal yang disetorkan, tanpa memandang apakah jumlah pekerjaan yang dilaksanakan oleh para mitra sama ataupun tidak sama. Ini adalah pandangan Mazhab Maliki dan Mazhab Syafi'i menurut mereka keuntungan adalah hasil modal karenanya pembagian keuntungan itu harus proporsional.

2. Pembagian keuntungan secara tidak proporsional

Mazhab Hanafi dan Mazhad Hanbali menyetujui pembagian keuntungan yang tidak proporsional terhadap modal bila para mitra membuat syarat-syarat tertentu dalam kontrak. Argumentasi merek didasarkan pada pandangan bahwa keuntungan adalah bukan hasil modal melainkan hasil interaksi antara modal dan kerja, bila salah satu mitra lebih berpengalaman ahli dan teliti dari lainnya, dibolehkan baginya untuk mensyaratkan bagi dirinya sendiri suatu bagian tambahan dari keuntungan sebagai ganti dari sumbangan kerja yang lebih banyak, Mazhab Hanafi dan Hanbali mendukung argumentasi ini dengan merujuk perkataan Ali bin Abi Thalib r.a " Keuntungan harus sesuai dengan yang mereka tentukan, sedangkan kerugian harus proporsional dengan modal mereka". Pendapat ini membantu dalam mempertimbangkan peran pengalaman, keahlian, jaringan dan efisiensi dalam mencapai keuntungan.

Berdasarkan pendapat kedua, keuntungan bersih yang diakui dapat dibagi sesuai masing-masing mitra dalam melakukan pekerjaanya. Keuntungan dialokasikan menurut bagian saham seperti mitra dalam total modal.

Sebagian ulama juga membolehkan pengalokasian bagian keuntungan yang sama kepada pihak ketiga. Misalnya, untuk fakir miskin atau organisasi kemanusiaan. Hal demikian harus disepakati oleh seluruh mitra. Demikian juga mengalokasian sebagian keuntungan sebagai cadangan untuk 
mendukung kondisi masa depan dari musyarakah.

e. Hukum Tentang Kerugian

Para ulama sepakat bahwa kerugian harus dibagi diantara para mitra secara proporsional terhadap saham masingmasing dalam modal. Mereka mendukung pendapat ini dengan perkataan Ali bin Abi Thalib r.a, “ Keuntungan harus sesuai dengan yang mereka tentukan sedangkan kerugian harus proporsional dengan modal mereka". Dalam hal musyarakah berkelanjutan (going concern) dibolehkan untuk menunda alokasi kerugian agar bisa dikompensasikan untuk menunda alokasi kerugian, agar bisa dikompensasikan dengan keuntungan pada masa-masa berikutnya. f. Hukum tentang Berhentinya Musyarakah Secara umum berakhirnya syirkah karena beberapa hal sebagai berikut :

1. Salah satu pihak membatalkannya meskipun tanpa persetujuan yang lainnya
2. Salah satu pihak kehilangan kecakapan mengelola harta.

3. Salah satu pihak meninggal dunia, tetapi jika anggota syirkah lebih dari dua, yang batal hanya yang meninggal dunia.

4. Salah satu pihak berada dibawah pengampunan

5. Jatuh bangkrut yang berakibat tidak berkuasa lagi atas harta yang menjadi saham syirkah.

Mayoritas utama kecuali Mazhab Maliki berpendapat bahwa musyarakah adalah salah satu bentuk kontrak yang diperbolehkan. Maka tiap mitra berhak menghentikannya kapan saja ia inginkan, sama halnya dalam kontrak perwakilan ketika salah satu mitra meninggal salah satu ahli warisnya yang balig dan berakal sehat, dapat menggantikan posisi mitra yang meninggal tersebut. Namun hal ini memerlukan persetujuan ahli waris lain dan mitra musyarakah. Hal demikian juga berlaku jika salah satu mitra kehilangan kompetensi hukumnya (Nawawi, 2012: 158). 


\section{Akad Pembiayaan Menggunakan Skema Musyarakah Mutanaqisah (MMQ)}

a. Definisi Musyarakah Mutanaqisah (MMQ)

\section{Musyarakah Mutanaqisah}

(MMQ) merupakan produk turunan dari akad musyarakah, yang merupakan bentuk akad kerjasama antara dua pihak atau lebih. Kata dasar dari musyarakah adalah syirkah yang berarti kerjasama, perusahaan atau kelompok/kumpulan. Musyarakah atau syirkah adalah merupakan kerjasam modal dan keuntungan. Sementara mutanaqisah berarti mengurangi secara bertahap. Musyarakah mutanaqisah (diminishing partnership) adalah bentuk kerjasama antara dua pihak atau lebih untuk kepemilikan suatu barang atau asset. Dimana kerjasama ini mengurangi hak kepemilikan salah satu pihak sementara pihak lain bertambah hak kepemilikannya. Perpindahan kepemilikan ini melalui mekanisme pembayaran atas hak kepemilikan lain. Bentuk kerjasama ini berakhir dengan pengalihan salah satu pihak kepada pihak lain (Hosen, 2009: 1).

Berlandaskan pada Fatwa Dewan Syariah Nasional Majelis Ulama Indonesia (DSN MUI) Nomor 73/DSNMUI/XI/2008 tentang Akad Musyarakah
Mutanaqisah dan keputusan Dewan Syariah Nasional MUI Nomor 01/DSNMUI/X/2013 tentang Pedoman Implementasi Musyarakah Mutanaqishah Dalam Produk Pembiayaan.

\section{Musyarakah Mutanaqisah} (MMQ) adalah salah satu produk pengembangan bebasis musyarakah. Musyarakah Mutanaqisah diaplikasikan sebagai suatu produk pembiayaan perbankan syariah berdasarkan prinsip syirkah inan, di mana porsi modal (hishhah) salah satu syarik (mitra) yaitu bank berkurang karena pembeli atau pengalih komersial secara bertahap kepada yang lain yaitu nasabah (Siregar \& Buchori, 2016: 134). Menurut Himpunan fatwa Keuangan Syariah, Syarik adalah mitra, yakni pihak yang melakukan akad syirkah. Hishhah adalah porsi atau bagian syarik dalam kekayaan musyarakah yang bersifat musya'. Musya' adalah porsi atau bagian dalam kekayaan musyarakah (milik bersama) secara nilai dan tidak dapat ditentukan batas-batasnya secara fisik. Perpaduan antara akad musyarakah berkurang (diminishing Musyarakah) dan ijarah menjadi suatu dasar untuk pembiayaan 
dalam pembelian rumah (Algaoud \& Lewis, 2001: 89). Berikut skema pembiayaan Musyarakah Mutanaqisah pada Perbankan Syariah :

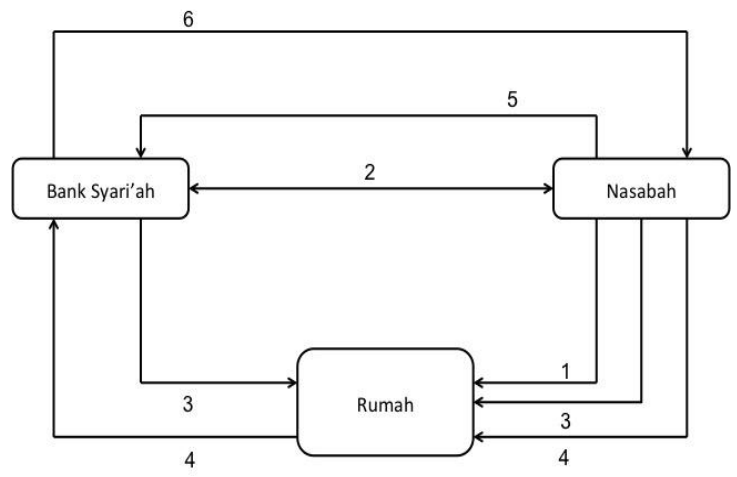

Sumber : Diadaptasi dari

Hosen (2009: 53)

Keterangan pada gambar diatas :

\section{b. Dasar Hukum Pembiayaan \\ Properti Menggunakan akad Musyarakah Mutanaqisah (MMQ)}

Pasal 3 Undang-Undang No : 21

Tahun 2008 Tentang Perbankan Syariah (UU Perbankan Syariah) mengatur bahwa perbankan syariah bertujuan untuk menunjang pelaksanaan pembangunan nasional dalam rangka meningkatkan keadilan, kebersamaan, dan pemerataan kesejahteraan rakyat. Selanjutnya Pasal 4 mengatur bahwa Bank Syariah dan Unit Usaha Syariah (UUS) wajib menjalankan fungsi menghimpun dan menyalurkan dana
1. Nasabah melakukan identifikasi rumah

2. Negoisasi dan kesepakatan pembiayaan antara nasabah dan bank syariah

3. Membeli rumah (masing-masing pihak berkontribusi sesuai modal yang disepakati)

4. Mendapat kepemilikan aset

5. Nasabah membayar angsuran berupa cicilan dan biaya sewa kepada bank syariah (bertahap)

6. Bank syariah menyerahkan hak kepemilikan rumah kepada nasabah (bertahap)

masyarakat atau fungsi intermediary dengan berasaskan prinsip syariah, demokrasi, dan prinsip kehati-hatian yang diatur dalam Pasal 2 UU Perbankan Syariah. Dengan demikian, akad MMQ sebagai alternatif pembiayaan perumahan merupakan implementasi dari ke tiga Pasal dalam UU Perbankan Syariah tersebut. Berkenaan dengan implementasi prinsip kehati-hatian dalam pembiayaan MMQ, Pasal 23 UU Perbankan Syariah mengatur syarat yang 
sama dengan UU Perbankan, yakni : (1)

Bank Syariah/Unit Usaha Syariah harus mempunyai keyakinan atas kemauan dan kemampuan calon Nasabah Penerima Fasilitas untuk melunasi seluruh kewajiban pada waktunya, sebelum Bank Syariah /UUS menyalurkan dana kepada nasabah penerima fasilitas.; (2) Untuk memperoleh keyakinan sebagaimana dimaksud pada ayat (1), Bank Syariah dan/atau UUS wajib melakukan penilaian yang saksama terhadap watak, kemampuan, modal, agunan dan prospek usaha dari calon nasabah penerima fasilitas.

\section{c. Syarat dan Ketentuan Akad Musyarakah Mutanaqisah (MMQ)}

Rukun Musyarakah Mutanaqisah $(M M Q)$ :

1. Sighah, ucapan ijab dan qabul

2. Pihak yang melaksanakan syirkah (kontrak)

3. Obyek kesepakatan

4. Nisbah bagi hasil

Syarat dalam akad Musyarakah Mutanaqisah (MMQ):

\section{METODOLOGI PENELITIAN}

\section{a. Jenis Penelitian}

Jenis penelitian yang dilakukan menggunakan penelitian kualitatif
1. Barang dan jasa harus halal sehingga transaksi atas barang dan jasa yang haram menjadi batal demi hukum syariah

2. Persentase pembagian keuntungan untuk masingmasing pihak yang berserikat dijelaskan ketika berlangsungnya akad. Keuntungan itu diambil dari hasil laba harta perserikatan, bukan dari harta lain

3. Modal, harga barang dan jasa harus jelas

4. Tempat penyerahan (delivery) harus jelas karena akan berdampak pada biaya transportasi

5. Barang yang di transaksikan harus sepenuhnya dalam kepemilikan. Tidak boleh menjual sesuatu yang belum dimiliki atau dikuasai seperti yang terjadi pada transaksi short sale dalam pasar modal. berbasis pendekatan deksriptif. Penelitian kualitatif ini bertujuan untuk menganalisa aplikasi akad Musyarakah 
Mutanaqisah (MMQ). Penelitian ini bersumber dari studi kasus yang menghasilkan input data kualitatif dengan bantuan observasi/wawancara, kemudian data tersebut diolah menggunakan analisis SWOT.

\section{b. Sumber Data}

Sumber data terdiri dari dua sumber, yaitu :

1. Data Primer

Data ini diperoleh melalui wawancara langsung dengan Bapak Indra Darmawan sebagai Head Of Relationship Manager SME Bank Muamalat Indonesia, dan wawancara terstruktur dengan Bapak Indra Darmawan sebagai Relationship Manager SME, Nadzira Qalbi sebagai Muamalat Officer Development Program (MODP), Bapak Aldi dan Ibu Nadhira sebagai nasabah KPR iB Muamalat.

2. Data Sekunder

Data ini diperoleh melalui studi dokumentasi terhadap laporan keuangan Bank Muamalat tahun 2018, panduan produk KPR Ib Muamalat Kongsi no. 01/RPDD/PMBY/2010, fatwa DSN MUI no. 73/DSN-
MUI/XI/2008 tentang

musyarakah mutanaqisah.

\section{c. Teknik Pengumpulan Data}

Teknik yang digunakan dalam penelitian ini adalah :

1. Riset Kepustakaan

Riset ini di maksudkan untuk mendapatkan acuan teori dalam melengkapi data yang ada. Dengan cara membaca buku-buku, mempelajarai literatur dan catatan yang berhubungan dengan akad pembiayaan musyarakah mutanaqisah, agar apa yang didapatkan benar-benar memiliki landasan teori dan acuan yang jelas.

2. Riset Lapangan

Ini dimaksudkan untuk mendapatkan data primer penelitian sebagai tekhnik pengumpulan data utama dalam hasil penelitian, yaitu dengan melakukan :

a. Observasi

b. Wawancara

c. Dokumentasi

\section{d. Teknik Analisis Data}

Metode analisis yang digunakan dalam penelitian ini adalah mengunakan konsep Miles dan Huberman. Dalam konsep Miles dan Huberman (1984), dikutip oleh 
Sugiyono (2012), dikemukakan bahwa tiga aktivitas analisis data. Aktivitas pertama yaitu

1. Data reduction, sebuah aktivitas menerangkan sehingga memudahkan pengumpulan data,

2. Data display, sebuah aktivitas menyajikan data agar

\section{HASIL DAN PEMBAHASAN}

\section{a. Aplikasi Pembiayaan}

Musyarakah Mutanaqisah (MMQ) Pada Bank Muamalat

\section{Indonesia}

Pada Bank Muamalat Indonesia, akad Musyarakah Mutanaqisah (MMQ) yaitu akad yang berpindah porsi kepemilikan, yang semula mayoritas dimiliki oleh pihak bank kemudian akan terus berkurang dan diakhir menjadi porsi kepemilikan kepada nasabah sepenuhnya. Dalam aplikasinya, akad MMQ digunakan untuk KPR properti jadi, properti baru (nonIndent) dan take over. Pada proses pengajuannya tidak ada perbedaan antara MMQ dengan akad Murabahah. Tetapi dalam akad MMQ pembelian rumah tidak melalui nasabah melainkan pihak bank langsung bertransaksi kepada pemilik properti. Harga yang diberikan kepada nasabah terorganisasikan dan mudah dipahami.

3. Conclusion drawing / verivication, sebuah aktivitas penarikan kesimpulan dan verifikasi berdasarkan buktibukti data yang telah dikumpulkan.

juga tidak ditambahkan dengan margin, tetapi harga asli dari pemilik properti.

Pada proses pengajuannya nasabah tidak hanya bisa mengajukan properti yang sudah bekerjasama dengan bank muamalat, melainkan nasabah bisa memilih properti yang diinginkannya, dengan syarat yang sudah ditentukan oleh bank muamalat yaitu akses menuju ke properti tersebut cukup untuk dilewati mobil dan motor secara bersamaan. Untuk proses take over pihak bank muamalat hanya akan membayarkan pokok dari pinjaman/pembiayaan kepada bank sebelumnya, sedangkan bunga maupun penalti akan dibebankan kepada nasabah.

Jika dalam perjalanan pembiayaan nasabah ingin mengajukan pelunasan maka, pihak bank akan memberikan diskon pada pelunasan 
tersebut. Diskon tersebut bersifat fluktuatif dan dapat didiskusikan kepada pihak bank. Juga pada proses penyelasaian atau jika terjadi Non Performing Financing (NPF) terhadap nasabah, maka pihak bank akan melakukan tindakan persuasif kepada nasabah, sehingga nasabah diberi kesempatan untuk bisa menyelesaikan permasalah tersebut sesuai perjanjian berikutnya. Dari tindakan penyelesaian yang menyebabkan NPF dari akad ini tergolong kecil, karena tangung jawab nasabah akan pembayaran angsuran sewa cukup tinggi. Dan juga pemindahan kepemilikan asset properti belum dilakukan sebelum proses pengalihan slesesai, sehingga pihak bank cukup diuntungkan pada akad ini.

Akad Musyarakah Muttanaqisah (MMQ) masih menjadi akad yang belum di maksimalkan oleh pihak BMI itu sendiri. karena akad ini tergolong akad yang rumit dibandingnkan dengan akad Murabahah pada pembiayaan KPR iB Muamalat. Nasabah yang datang ingin melakukan pembiayaan properti belum banyak mengetahui akad tersebut. Sehingga penggunaan akad tersebut menjadi sangat minim. Dari 100\% akad pembiayaan KPR iB muamalat hanya sekita $15-20 \%$ yang menggunakan akad Musyarakah Mutanaqisah (MMQ). Pada pembiayaan KPR iB Muamalat pembiayaan MMQ biasa digunakan untuk proses take over dari pembiayaan atau kredit bank lain. Akad ini digunakan karena adanya aturan dari Otoritas Jasa Keuangan (OJK) bahwa jika proses take over tidak boleh menggunakan akad yang sama. Jadi jika pada bank sebelumnya nasabah menggunakan akad murabahah pada pembiayaan properti, maka jika ingin di take over oleh BMI maka akadnya harus berbeda yaitu menggunakan MMQ.

Selain akad Musyarakah pada pembiayaan KPR Ib Muamalat juga menggunakan akad Ijarah. Akad ijarah digunakan pihak bank untuk mengambil keuntungan pada biaya sewa. Biaya ujrah dihitung berdasarkan presentase keuntungan bank dikalikan jumlah pembiayaan nasabah lalu dibagi jangka waktu pembiayaan yang diajukan nasabah. Pada BMI sendiri besaran sewa/ujrah yang dibayarkan nasabah setiap bulannya tetap. Tetapi bukan berarti biaya sewa akan tetap sampai akhir masa pembiayaan, akad MMQ juga terkena dampak evaluasi pada harga sewa kepada nasabah. BMI 
melakukan penyesuaian harga pada tahun ke 2 hingga tahun ke 6 pada pembiayaan KPR. Tergantung dari program yang diberikan dengan menggunakan akad ini. Tentu perubahan tersebut juga sudah diberitahukan kepada nasabah diawal perjanjian/akad dan sudah disepakati bersama. Walaupun begitu Hal tersebut menjadi salah satu keberatan nasabah yang ingin menggunakan akad MMQ.

Berikut skema pembiayaan akad Musyarakah Mutanaqisah (MMQ) pada Bank Muamalat Indonesia:

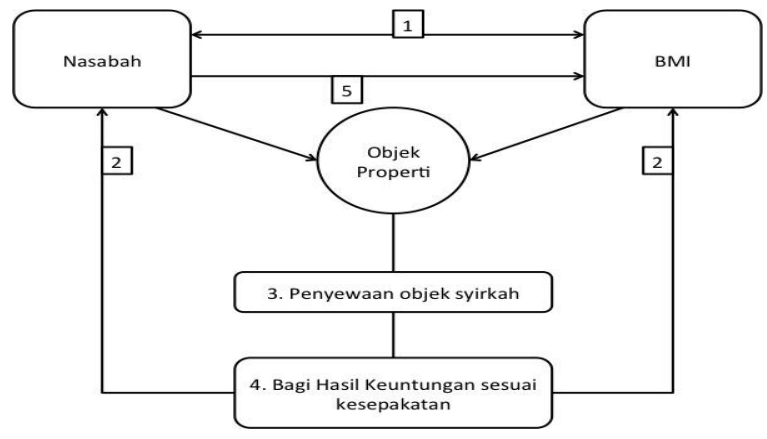

Sumber : Hasil Olahan Penulis

Keterangan :

1. Nasabah mengidentifikasi properti yang ingin dibeli dengan akad MMQ dan melakukan pengajuan pembiayaan dengan akad MMQ kepada bank

2. Nasabah dan bank melakukan akad MMQ dan bersama-sama menyertakan porsi syirkah masing-masing untuk membeli properti tersebut

3. Properti yang dibeli, disewakan kepada nasabah atau pihak ke tiga

4. Pendapatan sewa dari properti tersebut dibagi antara bank dan nasabah selaku pemilik sesaui dengan nisbah yang telah disepakati di awal

5. Nasabah membeli porsi syirkah bank dari pendapatan sewa yang diperoleh

Berikut skema Take Over menggunakan akad Musyarakah Muatanqisah (MMQ)

pada Bank Muamalat Indonesia (BMI) :

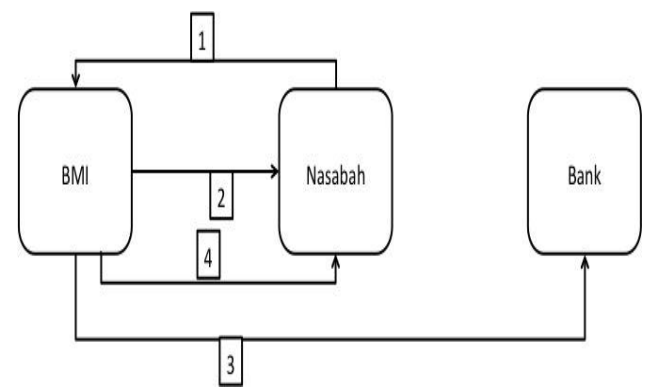

Sumber : Hasil olahan penulis

Keterangan :

1. Nasabah meminta BMI untuk menguruskan kepemilikan asset secara penuh 
2. Akad yang digunakan BMI kepada nasabah adalah akad Qardh (Pinjaman)

3. BMI membantu nasabah mengurus kepemilikan, dan

\section{b. Analisis SWOT Pada Akad MMQ}

Tahap ini adalah analisis SWOT

secara kualitatafi. Kulitatif adalah peneliitian yang menyajikan data dengan penggambaran sesuai dengan apa yang ada di lapamgan dan dianalisis menggunakan penginduksian dalam menjelaskan gambaran fenomena yang dilihat atau dicermati oleh peneliti (Gorman \& Clayton dalam Fiandana 2015: 1793).

Dalam analisis SWOT faktorfaktor internal dan eksternal saling berhubungan dan mempunyai keterkaitan satu dengan yang lainnya, dari keterkaitan dan hubungan tersebut dapat diperoleh strategi yang tepat untuk menetapkan kebijakan.

a. Strategi Kekuatan dan Peluang $(\mathrm{S}+\mathrm{O})$

Strategi keterkaitan kekuatan dan peluang harus melihat beberapa faktor yang ada, sehingga strategi tersebut dapat dijadikan sebagai acuan melunasi tanggungan nasabah kepada pihak Bank

4. BMI menyewakan asset kepada nasabah dengan menggunakan akad MMQ

untuk pengembangan model pembiayaan Musyarawakah Mutanaqisah (MMQ). Pertama, kekuatan metode pembiayaan Musyarawakah Mutanaqisah (MMQ) adalah bank syariah dan nasabah samasama memiliki atas suatu aset yang menjadi obyek perjanjian berkaitan dengan 1 (satu) peluang yang ada, yaitu Musyarakah mutaqisah (MMQ) merupakan gabungan dari dua, akad musyarakah dan ijarah. Kekuatan pengembangan fasilitas pelayanan dapat mendorong penggunaan musyarakah mutanaqisah.

Kedua, kekuatan yang dimiliki oleh Musyarakah Mutanaqisah (MMQ) adalah legalitas hukum terjamin berkaitan dengan 2 (dua) peluang yang ada, yaitu: Musyarakah Mutanaqisah (MMQ) merupakan gabungan dari dua akad, yaitu: musyarakan dan ijarah dan Musyarakah Mutanaqisah (MMQ) adalah bentuk inovasi produk perbankan syariah. Kekuatan dan peluang tersebut dapat dijadikan strategi untuk 
pengembangan

Musyarakah

Mutanaqisah (MMQ) sebagai prorok inovasi bank syariah yang sesuai dengan legalitas hukum yang ada.

Ketiga, kekuatan yang dimiliki oleh Musyarakah mutanaqisah (MMQ) adalah pembiayaan KPR dengan berbasis musyarakah mutanaqisah dapat mengikis resiko financial cost jika terjadi inflasi dan kenaikan suku bunga berkaitan dengan 2 (dua) peluang, yaitu perkembangan investasi properti di Indonesia dan meningkatnya pertumbuhan KPR syariah. Kekuatan dan peluang ini dapat dijadikan sebagai landasan untuk merumuskan kebijakan pengembangan pembayaran investasi properti dan KPR syariah untuk mengurangi financial cost jika terjadi inflasi dan kenaikan suku bunga.

Keempat, kekuatan yang diimiliki oleh Musyarakah Mutanaqisah adalah Pembiyaan KPR bersarkan sistem bagi hasil atas suatu usaha tertentu berikaitan dengan 1 (satu) peluang, yaitu musyarakah mutanaqisah merupaka gabungan dari dua akad, yaitu: musyarakah dan ijarah. Kekuatan dan peluang tesebut dapat dijadikan acuan strategi untuk pembuatan program pendukung pengaplikasian Musyarakah
Mutanaqisah (MMQ) sebagai metode pembiayaan yang merupakan gabungan dari dua akad.

Kelima. Kekutan yang dimiliki oleh Musyarakah Mutanaqisah adalah tidak ada sistem bungan dan penyitaan rumah dan kedua belah pihak (Bank Muamalat Indonesia dan nasabah) dapat menyepakati adanya perubahan harga sewa sesuai dengan waktu yang telah ditentukan dengan mengikuti harga pasar berkaitan dengan 2 (dua) peluang, yaitu: perkembangan investasi properti di Indonesia dan meningkatnya pertumbuhan KPR syariah. Kekuatan dan peluang tersebut dapat menjadi suatu strategi dalam rangka memberikan fasilitas kepada nasabah untuk mengembangkan investasi properti dengan pembiayaan yang bebas dari bunga.

b. Strategi Kelemahan dan Peluang $(\mathrm{W}+\mathrm{O})$

Strategi keterkaitan antara kelemagan dan peluang harus melihat beberpa faktor yang ada serta merumuskan peluang untuk mengatasi kelemahan produk Musyarakah Mutanaqisah (MMQ). Pertama, kelemahan yang dimiliki oleh Musyarakah Mutanaqisah (MMQ) 
adalah resiko terjadinya pelimpahan atas beban biaya transaksi dan pembayaran pajak, baik pajak atas hak tanggungan atau pajak atas bangunan, serta biayabiaya lain yang mungkin dapat menjadi beban atas aset tesebut. Kelemahan ini dapat diatasi dengan peluang yaitu Musyarakah Mutanaqisah (MMQ) merupakan gabungan dari dua akad, musyarakah dan ijarah dan musyarakah mutanaqisah adalah bentuk inovasi produk perbankan syariah. Kemudian, strategi yang dapat diterapkan untuk mengatasi masalah tersebut adalah melakukan pemantauan dan evaluasi terhadap pelaksanaan akad Musyarakah Mutanaqisah (MMQ).

Kedua, kelemahan yang dimiliki oleh Musyarakah Mutanaqisah (MMQ) adalah berkurangnya pendapaytan bank syariah atas margin sewa yang dibebankan pada aset yang menjadi obyek akad. Cicilan di tahun-tahun pertama akan terasa begitu membebankan nasabah, namun pada tahun-tahun berikutnya akan terasa meringankan. Kelemahan tersebut berkaitan dengan peluang Musyarakah Mutanaqisah (MMQ) berkaitan dengan peluang Musyarakah Mutanaqisah (MMQ) adalah bentuk inovasi produk perbankan syariah. Keterkaitan tersebut dapat menjadi sebuah strategi dengan potensi Musyarakah Mutanaqisah (MMQ) sebagai produk inovasi bank syariah, maka Bank Muamalat Indonesia harus memperbaiki sistem akad Musyarakah Mutanaqisah (MMQ) dengan inovasi-inovasi dan kebijakan baru.

Ketiga, kelemahan yang dimiliki oleh Musyarakah Mutanaqisah (MMQ) adalah biaya yang timbul pada akad, sepenuhnya dibebankan kepada nasabah. Kelemahan tersebut berkaitan dengan peluang perkembangan investasi properti di Indonesia dan meningkatnya pertumbuhan KPR syariah. Dengan demikian, strategi yang dapat diterapkan adalah mengkaji ulang peraturan Musyarakah Mutabaqisah (MMQ) untuk mendukung perkembangan investasi properti dan pertumbuhan KPR syariah.

c. Strategi Kekuatan dan Ancaman $(\mathrm{S}+\mathrm{T})$

Strategi keterkaitan antara kekuatan dan ancaman harus dilihat dari faktor-faktor yang bertujuan meredam ancaman dengan memnggunakan kekuatan yang ada. Pertama, kekuatan yang dimiliki oleh Musyarakah Mutanaqisah (MMQ) adalah bank 
syariah dan nasabah sama-sama memiliki atas suatu aset yang menjadi obyek perjanjian. Kekuatan yang dimiliki dapat mengatasi ancaman dalam pembiayaan Msuyarakah Mutanaqisah (MMQ) status kepemilikan barang masih menjadi milik bersama antara pihak bank syariah dan nasabah. Strategi yang dapat digunakan untuk mengatasi ancaman tersebut dengan kekuatan adalah menguatkan perjanjian kepemilikan barang untuk membina rasa saling percaya antara pihak bank dan nasabah.

Kedua, kekuatan yang dimiliki oleh Musyarakah Mutanaqisah (MMQ) adalah legalitas hukum terjamin dan pembiayaan KPR dengan berbasis Musyarakah Mutanaqisah (MMQ) dapat mengikis resiko financial cost jika terjadi inflasi dan kenaikan suku bunga. Ancaman yang dapat diatasi dengan dua kekuatan tersebut adalah praktek Musyarakah Mutanaqisah (MMQ) untuk pembiayaan barang terikat dengan peraturan atau regulasi yang berlaku. Ancaman tersebut dapat diatasi dengan kekuatan melalui strategi penetapan peraturan yang fleksibel untuk memberikan kenyamanan pada nasabah.
Ketiga, kekuatan yang dimiliki oleh Musyarakah Mutanaqisah (MMQ) adalah Pembiayaan KPR berdasarkan sistem bagi hasil atas suatu usaha tertentu dan kedua belah piha dapat menyekapakati adanya perubahan harga sewa sesuai dengan waktu yang telah ditentukan dengan mengikuti harga pasar. Ancaman yang dapat diatasi dengan 2 (dua) kekuatan tesebut adalah proses pelaksanaan pembiayaan Musyarakah Mutanaqisah (MMQ) yang dilakukan dengancara mengangsur setiap bulan akan terkena risiko kredit macet. Ancaman tersebut dapat diatasi dengan kekuatan melalui strategi melakukan komunikasi yang intensif antara pihak bank dan nasabah untuk perubahanperubahn yang terjadi menyangkut harga sewa dan waktu pembayaran.

Kesimpulan dari faktor kekuatan dan kelemahan tersebut di atas adalah menguatkan perjanjian kepemilikan barang untuk membina rasa saling percaya antara pihak bank dan nasabah, penetapan peraturan yang fleksibel untuk memberikan kenyamanan pada nasabah, dan melakukan komunikasi yang intensif antara pihak bank dan nasabah untuk perubahan-perubahn yang terjadi 
menyangkut harga sewa dan waktu pembayaran.

d. Strategi Kelemahan dan Ancaman $(\mathrm{W}+\mathrm{T})$

Strategi keterkaitan kelemahan dan ancaman harus melihat faktorfaktor, di mana kelemahan dan ancaman tersebut dapat dikendalikan untuk mengurangi dampak negatif yang berimbas pada jalannya akad Musyarakah Mutanaqisah (MMQ). Pertama, kelemahan yang dimiliki oleh Musyarakah Mutanaqisah (MMQ) adalah resiko terjadinya pelimpahan atas beban biaya transaksi dan pembayaran pajak, baik pajak atas hak tanggungan atau pajak atas bangunan serta biayabiaya lain yang mungkin dapat menjadi beban atas aset tersebut. Keterkaitan kelemahan tersebut dengan ancaman dalam pembiayaan Musyarakah Mutanaqisah (MMQ), status kepemilikan barang masih menjadi milik bersama antara pihak bank syariah dan nasabah dan praktek Musyarakah Mutanaqisah (MMQ) untuk pembiayaan barang terikat dengan peraturan atau regulasi yang berlaku. Strategi yang dibutuhkan adalah pelatihan dan pembinaan dalam bidang musyarkah mutanaqisah.
Kedua, kelemahan Musyarakah Mutanaqisah (MMQ) adalah berkurangnya pendapatan bank syariah atas margin sewa yang dibebankan pada aset yang menjadi obyek akad. Cicilan di tahun-tahun pertama akan terasa begitu membebankan bagi nasabah, namun, tahun-tahun berikutnya akan terasa ringan. Ancaman yang dimiliki oleh Musyarakah Mutanaqisah (MMQ) adalah praktek musyarakah mutanaqishah untuk pembiayaan barang terikat dengan peraturan atau regulasi yang berlaku. Keterkaitan antara kelemahan dan ancaman ini adalah peratutan yang bergitu mengikat akan berimbas pada terbebaninya salah satu atau kedua belah pihak dalam pelaksanaan akad Musyarakah Mutanaqisah (MMQ). Strategi yang dibutuhkan adalah merevitalisasi peraturan dan kebijakan Musyarakah Mutanaqisah (MMQ).

Ketiga, kelemahan yang dimiliki oleh Musyarakah Mutanaqisah (MMQ) adalah biaya yang timbul pada akad, sepenuhnya dibebankan kepada nasabah. Ancaman yang dimiliki oleh Musyarkah Mutanaqisah (MMQ) adalah proses pelaksanaan pembiayaan musyarakah mutanaqishah yang dilakukan dengan 
cara mengangangsur setiap bulan akan terkena risiko kredit macet. Keterkaitan antara kelemahan dan ancaman tersebut adalah pembebanan biaya kepada nasabah dapat menimbulkan kesulitan nasabah untuk mengangsur pinjaman setiap bulannya. Strategi yang dibutuhkan adalah menguatkan perjanjian antara bank dan nasabah dalam akad Musyarakah Mutanaqisah (MMQ).

\section{KESIMPULAN}

1. Kesimpulan dari faktor dan peluang MMQ adalah Kekuatan pengembangan fasilitas pelayanan dapat mendorong penggunaan musyarakah mutanaqisah, pengembangan Musyarakah Mutanaqisah (MMQ) sebagai produk inovasi bank syariah yang sesuai dengan legalitas hukum yang ada, pengembangan pembayaran investasi properti dan KPR syariah untuk mengurangi financial cost jika tejai inflasi dan kenaikan suku bunga, pembuatan program pendukung pengaplikasian Musyarakah Mutanaqisah (MMQ) sebagai metode pembiayaan yang merupakan gabungan dari dua akad, dan memberikan fasilitas kepada nasabah untuk mengembangkan investasi properti dengan pembiayaan yang bebas dari bunga.

2. Dari faktor kelemahan dan faktor peluang MMQ adalah melakukan pemantauan dan evaluasi terhadap pelaksanaan akad Musyarakah Mutanaqisah (MMQ), memperbaiki sistem akad Musyarakah Mutanaqisah (MMQ) dengan inovasi-inovasi dan kebijakan baru, dan mengkaji ulang peraturan Musyarakah Mutabaqisah (MMQ) untuk mendukung perkembangan investasi properti dan pertumbuhan KPR syariah.

3. Dari faktor kelemahan dan ancaman MMQ adalah pelatihan dan pembinaan dalam bidang musyarkah mutanaqisah, merevitalisasi peraturan dan kebijakan Musyarakah Mutanaqisah (MMQ), dan menguatkan perjanjian antara bank dan nasabah dalam akad Musyarakah Mutanaqisah (MMQ). 


\section{DAFTAR PUSTAKA}

Abdul Ghofur Anshori, Hukum

Perjanjian Islam Di Indonesia (Konsep,

Regulasi, dan Implementasi),

Yogyakarta: Gadjah Mada University

Press, 2010.

Adiwarman A. Karim, Bank Islam

Analisis Fiqih dan Keuangan, Jakarta:

PT RajaGrafindo Persada, 2017

Antonio, Muhammad Syafi'i, Bank

Syariah : Dari Teori ke Praktek, Jakarta:

Gema Insani, 2017

Dwi suwiknyo, Jasa jasa Perbankan

Syariah, Yogyakarta: PT Pustaka

Pelajar, 2010

Fajar Nur'aini DF, Teknik Analisis

SWOT, Yogyakarta: Quadrant, 2016

Ikatan Bankir Indonesia, Memahami

Bisnis Bank Syariah, Jakarta: PT

Gramedia Pustaka Utama, 2018

Ikatan Bankir Indonesia, Mengelola

Bank Syariah, Jakarta: PT Gramedia

Pustaka Utama, 2018
Ikatan Bankir Indonesia, Mengelola

Bisnis Pembiayaan Bank Syariah, Jakarta: PT Gramedia Pustaka Utama, 2015

Ismail Nawawi, Fikih Muamalah Klasik dan Kontemporer, Bogor : Ghalia

Indonesia, 2012

Muhammad Ridwan Basalamah dan Mohammad Rizal, Perbankan Syariah, Malang: Empatdua Media, 2018

Muhammad Syafi'i Antonio, Bank Syariah : Dari Teori ke Praktek, Jakarta: Gema Insani, 2017

Syed Nawab Haider Naqvi, Menggagas Ilmu Ekonomi Islam, Yogyakarta:

Pustaka Pelajar, 2009

Widodo, Metodologi Penelitian Populer \& Praktis, Jakarta: PT Rajagrafindo

Utama, 2019

Qaradhawi, Yusuf, Halal dan Haram, Bandung: Penerbit Jabal, 2014 
Tarmizi, Erwandi, Muamalat

Kontemporer, Bogor: Berkat Mulia

Insani, 2017

Wardiyah, Mia Lasmi, Pengantar

Perbankan Syariah, Bandung: Pustaka

Setia, 2019

Widodo, Metodologi Penelitian Populer

\& Praktis, Jakarta: PT Rajagrafindo

Utama, 2019 